\section{FedUni ResearchOnline}

\section{https://researchonline.federation.edu.au}

Copyright Notice

This is the peer-reviewed version of the following article:

Hale, R. (2020). Good Intentions: Women's Narratives of Post-Release Anticipatory Desistance in the Context of Historical and Contemporary Disadvantage and Trauma. Feminist Criminology, 15(5), 519544.

The online version of this article can be found at:

https://doi.org/10.1177/1557085120923403

Copyright (C) The Author(s) 2020 who receive access to an article through a repository are reminded that the article is protected by copyright. Users may download and save a local copy of an article accessed in an institutional repository for the user's personal reference. For permission to reuse an article, please follow the SAGE Process for Requesting Permission. 


\title{
Good Intentions: Women's Narratives of Post-Release Anticipatory Desistance in the Context of Historical and Contemporary Disadvantage and Trauma.
}

\author{
Dr Rachel Hale \\ Federation University Australia
}

\begin{abstract}
Desistance theorizing has concentrated on the male experience resulting in relatively less knowledge about how criminalized women negotiate non-offending, particularly from a qualitative perspective. Drawing on semi-structured interviews with eight formerly incarcerated women in Victoria, Australia, this research explores the anticipation of desistance in the context of experiences preceding and following incarceration. The findings highlight how individual-level intentions to cease offending can be eclipsed by historical and ongoing disadvantage and trauma. In emphasizing the gendered socio-structural barriers affecting women's desistance efforts, this article contributes to a small, yet important, emerging discourse - a form of critical feminist desistance.
\end{abstract}




\section{INTRODUCTION}

Criminological theories regarding the cessation of offending (desistance) flourished in the 1980s, extending on early age-based, maturational explanations (Glueck \& Glueck, 1937) to consider offender choice and rational decision-making (Clarke \& Cornish, 1985; Cusson \& Pinsonneault, 1986). The relatively young field of inquiry has since grown to examine the role of social bonds (Burnett \& McNeill, 2005; Farrington, 1992; Sampson \& Laub, 1993), cognitive transformation (Giordano et al., 2002), identity work (Farrall, 2005; Paternoster \& Bushway, 2009), and sociostructural influences (Farrall, et al., 2010; Maruna \& Farrall, 2004). Male behavior sits at the centre of most desistance studies, a characteristic that has not gone uncriticized (Barr, 2019; Massoglia \& Uggen, 2007; Thompson \& Petrovic, 2009). Subsequently, there is a lack of insight into the experience of negotiating, anticipating, and actualizing desistance for criminalized women, situating this article within a discourse fundamentally focussed on one portion of the offending population.

Criminalized women encounter unique challenges compared to their male counterparts, including increased financial insecurity, poverty and homelessness, and higher rates of intimate partner and sexual violence (Belknap, 2007; O’Brien, 2001). It is reasonable then to expect that male-based theories are unlikely to represent the reality of desisting for women. A 2016 review comparing the findings of 44 studies of female desistance with male-based desistance theories (Rodermond, et al., 2016) indicated that there are certainly common factors influencing desistance for both men and women, including social connectedness, employment, and abstaining from drug use. Nevertheless, qualitative studies revealed gender differences regarding the impact and importance of those factors, disparities that are no doubt influenced by the broader patriarchal structural conditions that lead to the criminalization of women - predominantly poor and Indigenous - to begin with (Barr, 2019).

Despite females comprising the minority of convicted offenders and prisoners, increasing global rates of female incarceration offer credence to the study of women's unique pathways into, and importantly out of crime. In the current neo-liberal climate of mass incarceration in western capitalist nations, of which the largest growth in imprisonment rates since the millennium has been witnessed for women (Walmsley, 2017), there is much to be gained from studying the desistance pathways of criminalized women. The aim of this current study, therefore, was to examine women's experiences pre-, during, and post-incarceration to understand the context of their desistance efforts, framed by the following research questions:-

1. What are the pre-offending life stories of the women and their pathways into crime?

2. What are the women's experiences with the criminal justice system, in particular in prison?

3. What are the women's experiences following, and in between, periods of incarceration? 
4. How do these experiences impact the capacity to desist from offending and reintegrate postrelease?

A sample of eight women participated in semi-structured interviews following imprisonment in Victoria, Australia. The insights of six post-release support workers were also included in the initial study, though their narratives are not presented to maintain the centrality of the voices of criminalized women. The women spoke about their experiences during childhood, pathways into offending, contact with the criminal (in)justice system, and journeys from custody to community and often times back again. All of the women had accumulated significant disadvantage and trauma across their lives, exacerbated by the painful experience of imprisonment. Following release, they encountered several barriers to (re)integration, returning to situations of socioeconomic disadvantage, housing instability, and continued substance abuse to cope with historical and contemporary trauma. These circumstances created substantial barriers to desisting despite that all of the women expressed intentions to cease offending.

Elaborating on these findings, this article considers the interface between micro-level factors, such as individual readiness and openness to desist, meso-level factors including community and familial influences, and macro-level obstructions namely societal and institutional discrimination. Contextualizing this analysis is a summary of what is known about criminalized women, followed by an overview of current theorizing about desistance from crime.

\section{CRIMINALIZED WOMEN}

It has long been acknowledged that criminalized women, particularly those who are Indigenous, are amongst the most severely disadvantaged people in society (Alder \& Hunter, 1999; Carlen, 1998; Easteal, 2001; Goulding, 2004; Peacock, 2008; Trotter et al., 2006). Women caught up in the criminal (in)justice system are often victims of significant disadvantage and trauma, occupying a dual-status as both victim and offender. Their social marginalization is characterized as a 'triple jeopardy' (Bloom, 1996) consisting of gender, race, and class-based discrimination, and therefore these women may be referred to as 'criminalized' (Segrave \& Carlton, 2010), challenging the euphemistic language of a discourse that has historically framed women as the only responsible agent for their offending (Maidment, 2006).

In this regard, criminalized women are not necessarily 'criminal' in nature (Hampton, 1993); rather they have been subject to state interventions that punish them for their disadvantage and trauma. The current research, in line with critical feminist scholarship, reinforces that female offending in such circumstances is not a rational choice but, often, a result of systemic and structural disadvantage 
(Maidment, 2006). Previous research has shown that the central issues influencing the initiation of offending for women sit often times beyond their control (Belknap, 2007; Bloom et al., 2003; Brennan et al, 2008; Chesney-Lind \& Shelden, 2004; Covington, 1998; Daly, 1992; Richie, 2001; Reisig et al., 2006). Indigenous women, specifically, are criminalized amid legacies of racism, forced separation and genocide that have occurred in the context of Australia's colonial history (Baldry \& Cunneen, 2014). Whilst the same needs may be evident with male-offending populations, these are amplified for criminalized women against a background of sexism, racism and classism in patriarchal settings (Chesney-Lind \& Shelden, 2004; Holtfreter \& Morash, 2003; Salisbury \& Van Voorhis, 2009).

As a result, criminalized women enter prison with a range of complex and compounding needs that intensify the penal burden they experience. Within prison, these needs are reconfigured as criminogenic via actuarial risk-assessment tools that conflate high-levels of disadvantage with 'riskiness' (Hannah-Moffat, 2005). Consequently, the most severely disadvantaged women are subject to increased surveillance and control by the state - they are imprisoned in maximum-security settings despite committing minor offenses, where they are rigorously monitored, controlled, and 'treated'. Such conditions exacerbate the historical trauma that these women have experienced, adversely affecting their health, particularly their mental wellbeing.

It is unsurprising then that many women return to the outskirts of the community following incarceration with worse problems than those they faced upon entry (Bosworth, 2003; Pollack, 2008), with some women struggling to (literally) survive post-release (Carlton \& Segrave, 2011). It is in the context of navigating these compounding needs that women negotiate desistance following release.

\section{DESISTANCE THEORIZING}

Desistance research examines the processes by and through which individuals stop offending (Byrne \& Trew, 2008; Gadd \& Farrall, 2004; Maruna, 2001; Vaughan, 2007). Considerable scholarly debate has ensued about how best to define and measure desistance (Farrall \& Calverley, 2006), concluding that desisting from crime is a process, not an event. This process is typically non-linear, characterized by peaks and lulls in offending (Ward \& Maruna, 2007), observable by decreases in the variety, frequency and seriousness of offending (Bushwy et al., 2001; Laub \& Sampson, 2001; Maruna, 2001). Pathways studies of desistance have therefore proved useful in uncovering the mechanisms by and through which individuals approach the termination of offending (Barry, 2007; Byrne \& Trew, 2008; Cobbina \& Miller, 2009).

In the current study the sample of women were all in the midst of contemplating a life free from offending - they were anticipating desistance. Friestad and Skog Hansen (2010) conceptualize anticipated desistance as the participant's optimism about avoiding crime in the future. In this regard, 
the degree of hope that an individual feels about desisting is important to their likelihood of actualizing desistance (Farrall \& Calverley, 2006). So too is 'self-efficacy' - the belief in an accessible pathway to action the desired change (Bottoms \& Shapland, 2010). It is here, at the juncture between good intentions and viable opportunities for change, that the intersection of agency and structure in the desistance process becomes apparent.

That individual agency is dependent on structural conditions is not a modern revelation (Bourdieu, 1977; Goffman, 1959), nor is it new to desistance studies (Farrall \& Bowling, 1999). Even so, malebased desistance research has sustained a focus on individual-level analyses, with a substantial body of work concentrated on internal cognitive transformation and associated narratives of change (Bottoms et al., 2004; Giordano et al., 2002; Healy, 2013; Maruna, 1997; 2001; Mulvey et al., 2004; Vaughan, 2007). Whilst these studies are undeniably valuable, a micro focus, alone, is insufficient given the socio-cultural context of 'crime', and therefore of desistance (Farrall et al., 2010). Even in research primarily focused on individual agency (Giordano et al., 2002; Maruna, 2001) it has been acknowledged that desistance involves a complex interaction of micro-, meso-, and macro-level processes (Nugent \& Schinkel, 2016).

Regarding the broader catalysts for desistance, or hooks for change, researchers have indicated variance along gender lines (Giordano et al., 2002; Laub \& Sampson 2003; McIvor et al., 2004). A primary example is the turning point of marriage, or more broadly, romantic relationships, about which there is consistent evidence that prosocial female partners encourage heterosexual male desistance (Shover 1996; Warr 1998; Laub \& Sampson 2003; Leverentz, 2006; Sampson et al., 2006). However, for justice-involved women whom are less likely to form a relationship with a prosocial partner (Laub \& Sampson, 2003; Lawrie, 2003), relational ties can be detrimental to desistance (Barry, 2007; King et al., 2006; Leverentz, 2006), particularly so in the context of male intimate partner violence (Barr, 2019; Galnander, 2019; Osterman, 2018). Similarly, employment has been queried for its utility in women's desistance pathways given the higher likelihood of women entering into low-level jobs post-release that may not offer the level of stability or gratification required to encourage desistance from crime (Cobbina \& Miller, 2009; Uggen \& Staff, 2001). Such findings indicate that male-based desistance theories do not make an unerring transfer to women, inspiring gender-specific theorizing.

Representing a critical feminist approach to understanding desistance is an emerging body of work focused on the structural conditions of women's criminalization and desistance (Barr, 2019; Barr \& Christian, 2019; Hart, 2017; Hart \& Van Ginneken, 2017; Österman, 2018). Bearing witness to the detrimental impacts of gendered disadvantage and trauma, Hart (2017) explored how 19 women serving prison sentences of three years or more in England prepared for life on the outside, finding 
that a lack of all forms of capital impeded the ability of them women to engage with resettlement services, hampering their chances of desisting long-term. Importantly, Hart set women's desistance in the context of the neoliberalist 'responsibilization agenda' (Garland 2001), emphasizing the inappropriateness of placing the onus for resettlement and desistance squarely on the individual woman given the broader (gendered) structural conditions that impede these processes.

Further insight into the structural context of women’s desistance was provided by Osterman's (2018) cross-national qualitative study of 24 adult women repeat offenders, 12 from Sweden and 12 from England, examining the impact of competing penal cultures - Anglophone Excess versus Nordic Exceptionalism - on women's pathways into and out of crime. Numerous gendered barriers to desistance were identified, including the detrimental role of intimate partners, and the difficulty securing employment due to child-rearing responsibilities, as well as the pressure to disclose criminal history information in feminized sectors. The Nordic welfare-state, characterised by equality, social cohesion, and an inclusive penal culture proved more conducive to desistance, providing the Swedish women with less pathway luggage (problems/challenges/harms) and more ladders (opportunities to overcome barriers) compared to the English women, evidencing how differential macro-structures impact women’s micro experiences of desisting.

Finally, Barr's (2019) research, based on the life-course narratives of 23 recently convicted women in England, challenged male-based desistance theories, namely social bond, maturation, and subjective explanations, finding them unsuitable for explaining women's pathways out of crime. Although likenesses to the male experience were evident, desistance appeared as a highly gendered process, requiring the women to resist and survive the patriarchal structural circumstances that initially led to their criminalization. Shame played a particularly pervasive role, with the 'double deviance' that the women experienced as offenders and 'bad mothers' hindering their efforts to pursue prosocial pathways. Barr's findings demonstrate that women's narratives of desistance can serve to challenge the patriarchal and neoliberal nature of male-based desistance theory.

This emerging body of critical feminist desistance discourse is a welcome departure from traditional androcentric, micro-level analyses. The current study similarly casts a light on the structural context of women's criminalization and desistance, positioning itself within this evolving space of critical feminist desistance inquiry.

\section{METHOD}

\section{Qualitative, Narrative Research}

Qualitative research offers insight into individual perceptions of life (Mishler, 1986) with the ability to reveal the frames by and through which individuals give meaning to their experiences (Hollander \& Gordon, 2006). Narrative research is capable of connecting historical experiences with future 
directions through a form of storytelling that connects the past, present, and future (GonzálezMonteagudo, 2011). In the imagining of future possible worlds (Bruner, 1986), narratives can reveal the goals that individuals seek to accomplish and the strategies they intend to employ to achieve them (McAdams, 1996). As such, narratives have emerged as a useful tool in studying desistance, enabling researchers to disentangle the meaning of relationships, events and experiences for male offenders (Maruna, 2001; 2004; Halsey, 2008) and more recently for criminalized women (Hart, 2017; Barr, 2019; Osterman, 2018).

Importantly, narrative inquiry can make hidden experiences known, such as those of minorities and the relatively disempowered, with the potential to reframe how we think about certain criminological concepts, in this case desistance from crime. In exploring the narratives of criminalized women - the 'forgotten offenders' (Carlen, 1983; Chesney-Lind, 1986; Morash et al., 1994) - this research gives voice to an alternative standpoint within a traditionally male-stream discourse, extending the legacy of critical feminist criminology (Carlen, 1983; Carrington, 1998; Chesney-Lind, 1986, 1989; Daly, 1992; Easteal 1992, 2001; Pollock-Byrne, 1990; Rafter, 1990).

\section{$\underline{\text { Recruitment }}$}

Six women were recruited with the assistance of two non-government support agencies. A further two women were recruited via snowball sampling. It was thought expedient to recruit women who had already been released from prison given the notorious barriers to accessing penal settings for independent research purposes (Scraton \& Moore, 2005). Interviewing women in the community strengthened the narrative accounts, as the participants were able to reflect on their reintegration and desistance efforts in the context of their release experiences. That prison officials did not monitor the women during the interview meant that they could speak openly without fear of reproach, a purposeful decision given the sensitive nature of the research. Although recruiting women in the community was anticipated as easier, significant challenges were encountered. These included difficulties identifying the appropriate gatekeeper within agencies that were under-resourced, as well as agency reluctant to be involved given the sensitive, and political, nature of the research topic.

\section{$\underline{\text { Participants }}$}

Eight formerly incarcerated women (as well as six post-release support workers) participated in the current study. The women ranged in age from 19 to 42 years. All participants had previously been incarcerated within the state of Victoria, Australia, on sentences spanning from two weeks (albeit followed by a longer episode in prison) to six years. Six of the women had been incarcerated once; one had been incarcerated twice; and one participant had been incarcerated on seven separate occasions. Seven of the women interviewed were Caucasian (of Australian background) and one woman was of Tongan heritage ${ }^{1}$. Seven women were living in urban areas of Victoria at the time of 
the interview, with one woman residing in a rural location. One participant reported having a disability - an acquired brain injury. The women are referred to herein using pseudonyms to conceal their identity and maintain their privacy.

\section{$\underline{\text { Semi-Structured Interviews }}$}

Narratives of anticipatory desistance were collected through semi-structured, audio-recorded interviews. Initially interviews were intended to be one hour in length but in some cases extended beyond this to almost two hours. Based on a pathways conceptualization of offending, the interview questions focused on the biographical histories of the women from early childhood, into offending, through incarceration to post-release. Follow-up interviews were attempted for all participants with the purpose of extending upon the initial interview and capturing any significant changes; yet only three participants were re-interviewed within the six months following the first phase of data collection. Such attrition is to be expected when engaging formerly incarcerated women for whom life following release can be chaotic and may involve periods of re-incarceration (Brown \& Ross, 2010).

\section{$\underline{\text { Data Analysis }}$}

Following transcription of the audio-recorded interviews, the data was analyzed thematically using a process of open coding. The transcripts were analyzed individually (vertically) and in comparison (horizontally) (Silverman, 2004) for key themes relating to the main research questions. Qualitative analysis software (NVivo) was used to verify the themes that were identified through researchermanipulated analysis. Themes were then organized into the various stages of interest (pre-, during, and post-incarceration) and were defined and clearly named, before a final review to check their distinctiveness and coherence.

\section{FINDINGS}

\section{Accumulation of Disadvantage and Trauma Preceding Incarceration}

Criminological concepts intrinsic to the study of ex-prisoner pathways are characterized by use of the prefix re, namely reintegration and rehabilitation, framing post-prison experiences, at least semantically, in terms of something that has come before. It is surprising, then, that biographical histories are often neglected when exploring post-release pathways. Early life experiences are fundamental to understanding offender needs and supporting ex-prisoners in a more effective manner (Brown \& Bloom, 2009). Biographical information surrounding the onset of offending provides invaluable context to pathways out of crime (Byrne \& Trew, 2008); therefore, the women in the 
current study were first asked to share their experiences from childhood through to their first offense, capturing the context of their lives prior to periods of imprisonment.

The relevance of historical experiences was palpable when the women began telling their respective stories and placing emphasis on their connection to subsequent offending. For all of the women, lifepreceding incarceration was characterized by disadvantage, violence, and subsequent trauma. The role of family was central to the women's narratives of early life. All of the women began their interview by negotiating a space in which they could discuss their disadvantaged and marginalized experiences in childhood, with all but one of the participants (Jodie) expressing how their familial environment played a critical role in their pathway into crime. Although the familial context for each woman differed, for all it placed them in a space of exclusion. Poor attachment, lack of parental monitoring and subsequent truancy characterized the familial context of offending. Interestingly, the women spoke primarily of the role of their mothers in their early lives and mentioned very little of their fathers, likely due to their father either being deceased, having left the family home, or being the perpetrator of violence against them as children.

Due to dysfunctional familial circumstances, all of the women found themselves in alternate living situations prior to their engagement in offending. The youngest participant, Mia, grew up in the care of her natural parents in rural Victoria, until the age of 14 when she decided to leave due to familial violence to live with her friends on the streets. Chelsea was also living on the streets by the age of 14 , fleeing sexual abuse that was perpetrated by men known to her family. Sam was raised by her grandparents until the age of six, and then by her birth parents until the age of 12, after which time she was placed in state care due to familial violence. Emma left home at the age of 12 due to the neglect she experienced by her mother, living on the streets and then in boarding accommodation. Caroline became a ward of the state at the age of 16, living in numerous foster homes until she was first incarcerated. Liz decided live independently in her late teens after her mother moved interstate to maintain a relationship with an abusive partner. Kylie started living with a violent male partner from the age of 14, triggered by her father's departure from the family home. The eldest participant, Jodie, revealed relatively little about her childhood other than to say that she was 'chucked out' of home by her mother and raised by seven men, moving houses often. For all of the women, living on the streets, in residential units and public housing estates, or in state-'care' saw them in frequent contact with individuals who were engaging in drug use and offending. As Mia explained:

We were living in the commission flats, not a good area, everyone else around was users and I just constantly found myself in punch-ons, and using, and stuff like that.

The women described these peer relationships as problematic because they reinforced drug use, as captured by Chelsea: 
Unfortunately, it allowed me to continue drug use because people were accepting that I used drugs. I was able to work and hold down a job, all the bosses that I had used to give me money and get me to score while I was at work, before I started work, while I was at work, I'd have a hit at work, so it wasn't a criminal act in my mind.

Intimate relationships were also evidently an entry point into drug use and offending. Kylie told of how she learned how to commit robberies from her partner:

I just started doing what I'd learnt all off him... I'd get my friends to distract and then I'd do the robbing of the cash register without them knowing and I'd leave.

So he taught me his habitual ways that I know now. And now that's why I won't go out with anyone else, cos I've had enough, and I'm sick of it and I won't teach anyone else how to do it.

Just as male partners for the women in heterosexual relationships were influential upon offending pathways, for the three women who were in same-sex relationships at the time of the interview, their female partners similarly encouraged drug use and offending.

Offenses committed with the aim of drug acquisition, including theft of money and goods, were prevalent amongst the sample, as has been identified with other criminalized women (Gelsthorpe et al., 2007; McIvor, 2007). Drug use evidently reduced the ability of the women to make rational decisions, as stated by Kylie:

Basically when you have a drug addiction, you're on a habit, running a habit.

You feel bad about doing it every day, but you have to do it because your whole body is cringing, your skin's crawling, your mind's just so on the prize you don’t care what you do ... but it has to be done because your body is full on like sick, you're that sick, you don't care, it has to happen, it has to be done.

Sam also described experiencing a lack of control over her behavior whilst under the influence of drugs:

I took some pills and apparently I walked into the 7-Eleven with a fit, a needle, and I held it to him [the store clerk] and demanded money and to be honest I could never do that, but I think I was that pilled, I dunno what drove me to do it but I took all the money and then hopped in the cab and then two minutes later I got caught.

Similarly, Caroline felt she was in a different state of mind when using:

It's hard to explain, but it does put you in a different head space. I can't just use that as an excuse, it's not an excuse. But every time I have broken the law it’s 
been under the influence of too much medication, either prescribed to me or somebody else and I've bought it from them.

Underpinning substance abuse were experiences of physical, emotional, and sexual violence. All of the women had experienced simultaneous instances of different forms of victimization, constituting 'polyvictimization' (DeHart \& Moran, 2015). For some women, their attempts to report their victimization as young people went unsupported by the adults around them. Chelsea stated that her parents knew about her childhood sexual abuse with the male perpetrators known to her parents. As such, her family provided no support to her in relation to her victimization. Similarly, Mia was sexually assaulted as a child and did not have a positive experience reporting her victimization to police, connecting it to her offending in the following way:

I think it started after I was like sexually assaulted and stuff and the police didn’t

do a lot and so I lost faith in the law and that's when I started going, 'Nah well stuff it', I'm just like, you know, they're going to let people like that off so I'm just going to run amok.

The marginalized and disadvantaged status of the women limited their access to normative methods for coping with victimization, and as a result, some women utilized self-harm, prostitution and substance abuse to self-medicate, as described by Chelsea:

I continued the drug use cos it blocked out all the stuff from the past and the issues that I had with family, myself, and all the shit from my childhood, it stopped that, and I have serious flashbacks and nightmares and stuff like that which are quite traumatic. Heroin didn't stop it but it allowed me to cope with it. These narratives represent the bounded agency (McNeill et al., 2011) characterizing the women's offending, wherein their lawbreaking behavior only made sense to them because of the context surrounding it. One particular theme that speaks to this bounded agency was the need for those women who were mothers to provide for their children in the context of poverty. Offending for these women was seen as acceptable if it meant they were being a 'good mother'. Emma revealed how she offended to fulfill her parental role, at the time not comprehending the consequences:

I stole [her] bassinet, breast pump, baby monitor. Cos I was scared that they'd say I didn’t have everything for her...I stole like every week, like I’d steal two outfits for clothes for her the whole time I was pregnant, so I had heaps of clothes... and I never thought of the consequences then, I just thought I need it. In describing their pathways into crime through the lenses of drug addiction and motherhood, the sample of women appeared not to think of their behavior as 'criminal' but rather as necessary, or at least understandable, in the context of the severe disadvantage and trauma they experienced early in life. 
The post-release success of ex-prisoners is typically measured by their ability to 'reintegrate', a term that, in its uncritical state, is misleading because it assumes a certain level of community integration preceding incarceration (Baldry et al., 2003). Following periods of incarceration, all of the women in the current study returned to excluded spaces on the periphery of the community wherein they faced the same, if not more severe circumstances of disadvantage than preceded their incarceration. From the margins of the community, the women attempted to negotiate their identity, relationships with others, involvement in offending, and survival. These experiences conflict with an uncritical conceptualization of reintegration, hence use of the term (re)integration here and the specification that the women were entering back into exclusion, not into mainstream society - an important, yet often unacknowledged, distinction.

The transition from custody to community was not easy for many of the women. Just as they had feared the carceral environment, they similarly feared returning to the outside, particularly following relatively longer periods of detainment, as is to be expected. The unpredictability of life outside of the structure and regimentation of prison life appeared to cultivate anxiety, including fear of the responsibilities and duties that come with independent living, the temptation of past friends and shared drug habits, of large crowds, of strangers, and, as Chelsea illuminated, a fear of their judgement:

Being too scared to go clothes shopping, me being afraid of being judged by people in society, not being able to be a normal person and when they ask me,

'Where are you from and what do you do?', what am I going to tell them? I’ve

been a heroin addict and a prostitute for the last 20 years of my life?

Transitioning from prison to the community was evidently an experience of shifting from a place of inclusion to exclusion for many of the women. Certainly, all of the participants experienced pains of imprisonment; experiences that cannot be suitably reflected upon here given their complexity and nuance, yet despite how painful prison was it presented fewer barriers than did life on the outside. Amidst the fear of transitioning from custody to community, the women were all released with a scarcity of material possessions, often only the items they possessed upon entry, and a very modest sum of money accrued on below-minimum-wage earnings whilst incarcerated. Sourcing an income was therefore a priority following release and beyond, with only one of the eight women employed at the time of the first interview (by the time of a follow-up interview, she had lost her job). Most of the women desired some form of employment, but not solely for the economic benefits. For those women with children it was an opportunity to position themselves to reunite and regain custody of 
their children. For those without children, employment represented independence, specifically from anti-social peers. Kylie emphasized the social benefits of employment:

I’ve been actually thinking in the last couple of weeks that I need a job, to get away from all of this. I'm just so sick of getting in with the same crowd and that's what's sending people back to jail, going with the same people... And now, if I want to set a goal, I’d be working, I’d be up there working. I wouldn't just be in a low-end [supermarket] job. I'd be up there.

There were disadvantages to employment expressed by some women, such as the reduction in access to welfare support that would incur if they worked full-time hours and the impost on parenting responsibilities. Chelsea explained how she chose to work part-time to maintain her place on the public housing waiting list:

I'm on the waiting lists for government housing... and now that I'm working I don’t qualify. You're in a catch 22 either way; as soon as I'm now working I don’t qualify for public housing. I’ve taken a job where I'm only working parttime so that if my hours start to affect stuff like housing.

These experiences highlight the entrenchment of disadvantage in the women's lives and the subsequent dependency on government support that influenced the pursuit of 'unconventional' means of financial stability. Unemployment following imprisonment has been linked to post-release recidivism as a means to acquire money for subsistence (Peacock, 2008), and this was certainly evident for these women, many of whom had committed acquisitive offenses following periods of incarceration. Some women were also dependant on others, such as partners or family for financial support. Financial independence was expressed as essential to disengaging with antisocial, drug-using peers, serving as a key motivator to finding employment. However, when the women did seek employment opportunities, having a criminal record posed significant barriers. Certain occupations were unviable, such as working with children or as a social worker due to the presence of a criminal record, and given that most of the women (aside from Kylie) left school early, they had few formal qualifications, aside from those obtained in custody. The types of industries that the women did gain experience in during incarceration, such as horticulture or hospitality, were not necessarily desirable to them following release. All of the women felt that their prospects of finding meaningful employment were minimal given their histories of disadvantage.

Without a stable income, maintaining long-term, private accommodation was a challenge for all of the women upon return. Owing to periods of incarceration, some women were not formally identified as being 'homeless' whilst in prison and therefore were not provided with support in this domain, or they were removed from public housing waiting lists, unable to apply for government housing in 
advance of their release. The women therefore had very little choice and control over where they were living, as Emma explained:

It’s like Housing goes ‘you're a criminal go live [here], oh you're a drug addict you can live there too'. If I could've said no I would've said no to here. It was either stay in jail or take this place and before I even saw it, I had to agree to take this place.

Without stable employment and safe, secure accommodation, those women with children encountered significant barriers to reunification. Of the five women who were mothers, only two of them had acquired full custody of their children after release. Forced separation from their children was a great source of distress and evidently fuelled the women's feelings of failure and sense of hopelessness. Seeking to overcome these barriers, all of the women at some point following their release had accessed community-based support services. Despite this, some women felt that they had not received adequate support to address their substance abuse, mental illness, and historical legacies of victimization, specifically, though the provision of support was appreciated. The primary agency with which the women engaged assist adult women with their re-settlement needs, primarily the acquisition of housing. This agency has the ability to connect with women in prison and therefore relationships may be established prior to release, which was the case for some women in this sample and appeared quite helpful in fostering a stronger relationship between support worker and client. The other community-based agency supports young people who have come into contact with the youth justice or residential care systems across the state, supporting them to connect with education, recreation, and employment opportunities, namely through mentorship. The psychological and physical health needs of the women were therefore addressed by other, specialist agencies, access to which often took significant time and effort on the woman's behalf.

All of the women expressed that the circumstances they were living in following release from prison were challenging, chaotic, dysfunctional, and reminiscent of the spaces they had occupied for most of their lives. The women had evidently not reintegrated into the mainstream, but had returned to the margins from where they negotiated and anticipated desistance from crime.

\section{Anticipating Desistance From The Margins}

Upon returning to the periphery of the community following incarceration, all of the women faced significant barriers to participating in mainstream, prosocial, society. Experiences of disadvantage and exclusion reconfigured prison as a place of safety and security in comparison to life in the community. This was an obvious threat to desistance with all of the women expressing that life in prison was far easier than navigating life in the community. Some women, such as Chelsea, had subsequently contemplated reoffending with the aim of returning to prison: 
When I'm really lonely and things aren’t going well for me out here the thought has crossed my mind numerous times that 'Fuck it, I'll go out and reoffend and I’ll make sure it's a good one this time so I get a really long holiday this time'... which means I’m gonna go out and do a serious crime.

The inaccessibility of safe and secure housing was a significant barrier to desistance. Due to this, all of the women were living in environments surrounded by others who were engaging in drug-related behavior, including selling and consuming illegal substances. The inability of some women to choose where they lived following imprisonment evidently forced them into situations that were not conducive to their desire to cease drug use and offending. For example, Chelsea hitched a ride from a stranger whom she ended up living with, and despite that he did not support her sobriety she chose to stay with him as she had nowhere else to live:

Without him I'd have nowhere to go, but he is an 'at risk' person and is somebody that is not a good influence in my life. I get very frustrated and very annoyed and it's a reminder of the person I used to be and he still treats me like the drug addict and ex-working girl and I don’t need that. But I can’t afford private rental, there is no government housing.

For many women, ceasing drug use and offending meant actively evading the people they had been close friends with prior to their incarceration, which often left them isolated and lonely. The boredom created by such isolation influenced many women, including Liz, to turn to drugs:

Yeah cos you're bored, you're depressed about your own life and you do, you turn to drugs to escape. Like, you just don't wanna think about that so you have stuff to escape it all.

Similarly, Emma connected her drug overdose to her social isolation:

I don't know whether I wanted to take the drugs. Not saying I was forced to, but whether I really wanted to take them or just didn’t know what to do. I had no friends in Melbourne; I still don't know anyone in Melbourne really.

These accounts show that, even when actively choosing to separate themselves from anti-social peers in an effort to desist from drug use and offending, the women were concurrently increasing their risk of relapsing and reoffending.

Building relationships with prosocial individuals was one strategy that some women employed to increase their social inclusion. However, accessing conventional peer networks was not easy given that many of the women had never belonged to the mainstream to begin with. Chelsea expressed a desire to connect with prosocial individuals, but did not know how to go about actioning her intentions: 
I know that I'm only doing this recreational drug use cos of the partner I've currently got cos he recreationally uses...I don't want that. I want people in my life that are like yourself and, this is where I still have a long way to go...I want great people in my life, I don't have them. I literally don’t and I don’t know how to get them.

Efforts to be agentic by re-positioning oneself within mainstream society were evidently hindered by the 'ex-prisoner' label and the associated stigma which all of the women reported experiencing at some point following release. Constant reinforcements of this label, either by others within the community or through processes that required the disclosure of criminal history information, led some women to feel as though their efforts to 'go straight' were futile. Maintaining motivation to desist from crime was therefore challenging for all of the women given the unrelenting barriers they faced when attempting to pursue prosocial pathways. Continual barriers to the pursuit of desired pathways, and the associated sense of 'failing' evidently led many of the women to become intermittently apathetic about desisting. Interestingly, it was often their failure to cease drug use that the women felt most demotivated by, which was closely tied to anti-social peer relationships, whereas failures to desist from crime were not viewed as negatively given that such offending was grounded in need. Yet, despite the women expressing a lack of control over their ability to achieve a conventional lifestyle given the structural barriers to their participation in mainstream society (indicative of low selfefficacy), most women persisted in their pursuit of a prosocial identity.

The women described their efforts to desist in line with a process-based definition, communicating that it would take substantial time, effort, and resources to cease offending, and drug use. Sam likened it to the process of changing ones diet:

It's like eating, you don't just stop eating. Even if you're trying to diet, it's the same as drugs; you kind of just go down and down and get off the bad shit. Same with the diet, you don't just go straight onto health food cos you still got all the junk food, you got to slowly clean out the cupboard you know.

For Liz, a decrease in the frequency of her drug use was viewed as a success, as with Chelsea who said:

...I had a couple of hits fortnightly and then it got to weekly for about two to three months I did go back every couple of days, or you know, four to five days a week, but managed to pull myself out of it. I now currently haven’t used heroin for a couple of months now. When I did use it was only a one-off.

Regarding the motivation to desist from crime, for most of the women this stemmed from a sense of being fatigued by their engagement in drug use. 
Beyond this, the five mothers in the sample communicated that their children were the primary motivator to desist, as well as an impetus for reoffending, a thought-provoking contradiction. These women explained how they would continue to engage in offending after release if their children needed something that they could not provide. Emma disclosed how she had stolen petrol following incarceration to keep her children, and those of a close friend, safe:

...we had no money left over for petrol and the fact that if any of the people we had the restraining order against ... if they come in the middle of the night like we had nowhere to go except for to a bus stop. But how safe is that?...Just to make sure I could get [my daughter] out of there if I had to and to make sure I could get her kids out of there, and her if her ex-boyfriend turned up. I would've payed for it if we had money, but I just went and filled up the car when we needed to and stuff....

Despite their continued offending many of the women in the sample did not identify themselves as being 'criminal' in nature. When the women did use this term they clarified that they were referring to the way that other people viewed them. Emma believed it was 'naive' of others to label her 'criminal' or 'druggy' because it showed no understanding of her character or circumstances. Although the women did not perceive themselves in accordance with these negative labels they were clearly concerned with and affected by the perceptions of others. In this vein, all of the women were acutely aware of their position on the margins of society and they all expressed a desire to occupy different spaces in the future, as difficult as they perceived the accomplishment of those good intentions to be.

\section{DISCUSSION}

Criminalized women are pushed into marginal spaces early in life (Baldry, 2010), and the findings of this current research highlight the nature of the historical and contemporary disadvantage and trauma that characterizes these spaces. The women traversed numerous paths to crime that have been defined previously in seminal pathways research, namely those framed by drug use, victimization, and homelessness (Brennan et al., 2008; Daly, 1992, 1994; Salisbury \& Van Voorhis, 2009). Before their first arrest, all of the women in this study had experienced issues relating to familial detachment, victimization, truancy, transiency, and drug use, indicating a significant level of trauma before entering the prison system. It is understandable then why the women described their offending as a means of 'coping', similar to the findings of previous, qualitative research (Bloom, Owen, \& Covington, 2004).

Experiences of victimization in childhood and adolescence were pervasive across the sample, which is not unusual for justice-involved women (Chesney-Lind \& Pasko, 2013). Experiencing and 
witnessing violence pushed the women away from normative institutions of support, such as the family and school (DeHart, 2008), and into the company of antisocial peers with whom they engaged in drug use to manage the traumatic nature of their lives. In particular, intimate partners encouraged and enabled the women's drug use, both in heterosexual and lesbian relationships, which subsequently sustained the women's offending, reflective of previous research wherein romantic partners have proved to be a stimulus for offending rather than encouraging of prosociality for women (Barry, 2007; Barr \& Christian, 2019). These experiences entrenched the women in cycles of drug use and offending which eventually led to their imprisonment.

Despite conveying numerous pains of prison life, all of the women experienced a sense of inclusion whilst in prison that was disrupted upon release. One of the most salient themes of the women's immediate release experiences was the fear of returning to the community given that they had lost what little they did have prior to entering prison. The isolation and loneliness that the women felt, because they choose to distance themselves from old friends and because they did not know how to make new prosocial connections was overwhelming and for many led to continued substance abuse. Compounding the experience of returning, therefore, was the complex process of recovering from addiction - positioned as a priority for all of the women beyond desisting from crime. The distinct challenges in overcoming drug addiction, a significant issue for many individuals engaged with the criminal justice system, undeniably differ from the kinds of shifts in identity that are referred to within the desistance literature, with a need for further research into the nexus between recovery from drug addiction and desistance from crime. In highlighting the saliency of addiction to women's offending pathways, the efficacy of imprisonment as a criminal justice response must be disputed here. Not only does incarceration punish the individual for what is a health problem, it is also an ineffectual mechanism to address the trauma and disadvantage that often underlies such addiction. It is unsurprising, then, that imprisonment impedes desistance from crime, a point to be emphasized through a critical approach to desistance theorizing (Hart, 2017).

Considering the experiences of the women in this study holistically, it is obvious that the disadvantage and trauma they experienced post-release was familiar to them - most of the women were noticeably well acquainted with marginalization having experienced significant hardship since childhood, signalling the cumulative nature of their disadvantage and trauma. The trauma the women experienced was fluid and recurrent, not isolated to a specific event, comparable to that which Segrave and Carlton (2010) refer to in their Surviving Outside research. It did not coalesce at one definable point in time and certainly did not spontaneously manifest following release from prison. The accumulation of severe trauma and disadvantage over the life course had a significant impact on the women's post-release pathways, in particular their inability to integrate into the mainstream 
community. It has been acknowledged previously that following imprisonment most individuals do not return to the mainstream community (Hart, 2017; Wacquant, 2010). The enduring and persistent nature of marginality for the women in this study demonstrates that they were not reintegrating into the mainstream following incarceration but rather were reintegrating into exclusion - a concept that may serve to broaden the existing discourse to reflect the complex reality of returning for many formerly incarcerated persons, not just women.

Within these marginal spaces, the women attempted to reduce their involvement in offending, however this often led them to feel the pains of desistance (Nugent \& Schinkel, 2016) in the form of loneliness, guilt, and a sense of hopelessness. Many women expressed that they had no other option than to re-offend in order to survive in the absence of multiple forms of capital, aligning with the findings of Hart's (2017) research with women prisoners in England. This was most relevant to the mothers in the sample, who, though describing their children as a significant motivator to desist (Giordano et al., 2002), simultaneously reoffended to provide for, or reunite with, their children. To this end, ceasing offending was not necessarily a priority; some women considered merely perpetrating less crime as a success in the face of their severe lack of capital. These narratives query whether desisting really is important for criminalized women above the pursuit of a 'better life' (Baldry, 2010), one which may still necessitate offending, supporting the call from critical scholars for a rethinking of recidivism as a useful measure of the success of individuals following incarceration (Carlton \& Segrave, 2013; 2016; Maidment, 2006; Pollack, 2009).

Achieving a more permanent state of desisting is thought to involve a significant cognitive shift in identity from a criminal to a prosocial self-concept (Maruna \& Farrall, 2004). Contrastingly, the women's narratives indicate that such a cognitive reorientation away from a 'criminal' identity may not actually be as relevant to them given that their offending stemmed from need rather than some inherent predilection to criminality. In this context, any identity work that may occur is essentially ineffectual without corresponding changes to the socio-structural environment within which personal volition is exercised. As Laub and Sampson (2001) indicated, successful desistance occurs when the immediate causes of offending are addressed. For the women in this study, like many criminalized women, those causes are primarily structural in nature.

Structural barriers, just as they influence the onset of offending, also have the power to impact upon desistance, even for those who express a readiness and willingness to cease offending (Galnander, 2019) as was evident for the women in this study. Without opportunities to engage in the mainstream, to connect with prosocial members of the community, to be and to feel included, the individual is relegated to the margins, where good intentions are not supported to materialize into meaningful change. This underscores the importance of moving beyond a narrow focus on the within-individual 
changes involved in desisting to examine the broader social, economic, institutional, and political influences over individual intentions to desist, in turn challenging the state to address these barriers. In the absence of state-driven change, service providers are somewhat constrained in the extent to which they can support their client's to desist. Although those who work directly with criminalized women may be unable to address such things as the availability of appropriate employment opportunities for women, or the amount of secure long-term public housing stock, there are certainly areas in which support provision appears to be considerably impactful in supporting desistance. All of the women in this study emphasized the centrality of their relationship with their support workers to their efforts to pursue prosocial relationships; these relationships were sometimes the only prosocial connection that the women had in their lives. Based on the challenges that the women in this study experienced in attempting to forge the conventional relationships that they desired, those programs that encourage and facilitate such connections, for example mentoring, may prove particularly beneficial in providing women with supportive spaces from which they can pursue their goals. Furthermore, as the women's experiences in this study show, pathways to desistance are nonlinear and often involve 'failures' in desisting. Despite recurrences of offending all of the women expressed a desire to continue their pursuit of prosocial pathways, indicating the importance of practitioner persistence and enduring support throughout this fluctuating process.

In considering the findings of this study, a number of limitations should be noted. Firstly, time constraints necessitated the expeditious recruitment of participants, which resulted in an inability to recruit a larger, and more diverse, sample of criminalized women. Whilst saturation was reached, facilitated by the depth of the women's narratives and inclusion of support worker perspectives, a consequence of the limited sample in the current study is the inability to generalize the findings, particularly to criminalized women from ethnic minority communities, namely to Indigenous women. Secondly, these same constraints meant that pursuing a longitudinal study of women's desistance was not possible. This has resulted in an insight into the anticipation of desistance for women in the months directly following release from prison, but not beyond that to the years that follow, across which time significant changes may occur. The study could therefore have been strengthened through engagement with a more diverse array of perspectives and voices of criminalized women, exploring the long-term shifts in desistance pathways over an extended period of time - important considerations for future research design.

\section{CONCLUSION}

Within the current neoliberal climate dominating criminal justice responses in western countries, including Australia where this research was undertaken, it is in the stake of the state to responsibilize the individual for their offending in order to evade culpability for the disadvantage and trauma that 
surrounds it (Barry, 2016). Studies of desistance ought not to replicate this agenda. Through critical examinations of desistance, such as this, the punitive and actuarial ideologies of the state can be challenged, particularly by bearing witness to the unique experiences of marginalized groups for whom mechanisms of criminalization have the most severe impact. The harmful acts that the state committed against these women, such as forcibly separating them from their families and children, failing them as victims of crime, subjecting them to the pains of imprisonment in response to relatively minor offenses, and then releasing them back to the margins expecting some form of reformation, warrant accountability.

The women's histories reveal how state neglect and violence does not commence with incarceration. As has been evidenced in previous research (Carlton \& Segrave, 2011; Maidment, 2006), these harms extend beyond the prison into other social institutions with which disadvantaged women interact early on in their lives, such as the education, welfare and state 'care' systems. It is important then that calls for transformative change are not limited to an abolitionist position of dismantling prisons (as vital as this is), but extend beyond this to advocate for the termination of the broader socio-political processes that produce structural inequalities, including the criminalization of disadvantage and trauma.

Criminalized women are one of the most vulnerable and silenced groups within society, therefore critical desistance inquiry should continue to bear witness and give voice to these experiences through qualitative methods, countering the persistent androcentric narrative of the discipline. Echoing Chesney-Lind's (1989) call for a feminist theory of delinquency, there is a current need for feminist approaches to understanding desistance that are perceptive to its patriarchal context. In particular, further research from an intersectional feminist perspective is required to capture the interrelating nature of gender, class, and race-based discrimination and violence and the impacts on women's pathways to desistance.

Further to that, future desistance research with a global focus would be advantageous, examining the impact of location or place on desistance, and how this intersects with gender (amongst other factors). Advancing cross-cultural studies of women's desistance pathways (see Osterman, 2018) would assist in identifying the role of disparate legislative, policy, and service contexts in either promoting or inhibiting desistance. Similarly, studies comparing desistance experiences across rural versus urban locals would be beneficial to understanding how the unique socio-cultural context of rural communities' affects the efforts of criminalized women to cease offending. Particularly given that in some such communities there can be amplified traditionalist, conservative and patriarchal values and attitudes that may have significant impacts on women's (re)integration and desistance efforts. 
Drawing on the findings of desistance research to influence significant legal and social reform is a vital next step. Adopting the learnings from desistance studies, like this one, to detect and disrupt inappropriate and injurious responses to women's offending will help to stem the criminalization and harm of women such as those who so courageously shared their stories for this research and the many others who remain silenced.

\section{NOTES}

${ }^{1}$ The distinct experiences of Indigenous women were unfortunately not captured given that no such women expressed interested in participating. Capturing these unique standpoints, and the intersecting impact of gendered and racialized discrimination and violence, is extremely important as these experiences are not widely examined within desistance research.

\section{References}

Alder, C., \& Hunter, N. (1999). Not worse, just different: Working with young women in the juvenile justice system. Criminology Research Council: Canberra.

Baldry, E., \& Cunneen, C. (2014). Imprisoned Indigenous women and the shadow of colonial patriarchy. Australian \& New Zealand Journal of Criminology, 47(2), 276-298. https://doi.org/10.1177/ 0004865813503351

Baldry, E., McDonnell, D., Maplestone, P., \& Patterson, M. (2003). Ex-prisoners and accommodation: What bearing do different forms of housing have on social reintegration. Australia: Australian Housing and Urban Research Institute (AHURI). https://www.ahuri.edu.au/research/final-reports/46

Baldry, E. (2010). Women in Transition: From Prison to. Current Issues in Criminal Justice 22(2), 253-267.

Barr, U. (2019). Desisting Sisters Gender, Power and Desistance in the Criminal (In)Justice System. Imprint: Palgrave Macmillan.

Barry, M. (2007). The transitional pathways of young female offenders: Towards a non-offending lifestyle. In R. Sheehan, G. McIvor \& C. Trotter (Eds.), What works with women offenders (pp. 23-39). Cullompton: Willan Publishing. 
Barry, M (2016). On the Cusp of Recognition: Using Critical Theory to Promote Desistance Among Young Offenders. Theoretical Criminology 20(1): 91-106.

\section{https://doi.org/10.1177/1362480615586613}

Belknap, J. (2007). The invisible woman: Gender, crime, and justice (3rd ed). Belmont: Thompson Wadsworth.

Bloom, B., Owen, B., \& Covington, S. (2003). Gender-responsive strategies: Research practice and guiding principles for women offenders. Washington: Department of Justice, National Institute of Corrections. https:// www.nicic.org/pubs/2003/018017.pdf

Bloom, B. (1996). Triple jeopardy: race, class and gender as factors in women's imprisonment. Riverside: University of California. http://search.proquest.com/docview/304228714/

Bloom, B., Owen, B., \& Covington, S. (2004). Women offenders and the gendered effect of public policy. Review of Policy Research, 21(1), 31-48. https://doi.org/10.1111/j.15411338.2004.00056.x

Bosworth, M. (2003). Gender, race, and sexuality in prison. In B. H. Zaitzow \& J. Thomas (Eds.), Women in prison. Boulder: Lynne Rienner.

Bottoms, A. E., \& Shapland, J. (2010). Steps towards desistance among young adult recidivists. In S. Farrall, R. Sparks, S. Maruna \& M. Hough (Eds.). Escape Routes. London: Routledge.

Bottoms, A., Shapland, J., Costello, A., Holmes, D., \& Muir, G. (2004). Towards desistance: Theoretical underpinnings for an empirical study. The Howard Journal of Criminal Justice, 43(4), 368-389. https://doi.org/10.1111/j.1468-2311.2004.00336.x

Bourdieu, P. (1977). Outline of a theory of practice. Cambridge: Cambridge University Press.

Brennan, T., Breitenbach, M., \& Dieterich, W. (2008). Towards an explanatory taxonomy of adolescent delinquents: Identifying several social-psychological profiles. Journal of Quantitative Criminology, 24(2), 179-203. https://doi.org/10.1007/s10940-008-9045-7

Brown, M., \& Bloom, B. (2009). Re-entry and renegotiating motherhood: Maternal identity and success on parole. Crime \& Delinquency, 55(2), 313-336. https://doi.org/10.1177/0011128708330627

Brown, M., \& Ross, S. (2010). Mentoring, Social Capital and Desistance: A Study of Women released from Prison. The Australian and New Zealand Journal of Criminology 43(1), 31-50. https://doi.org/10.1375/acri.43.1.31

Bruner, J. S. (1986). Actual minds, possible worlds. Cambridge: Harvard University Press. https://doi.org/10.1016/0005-7967(87)90029-5 
Burnett, R., \& Maruna, S. (2006). The kindness of prisoners: Strengths-based resettlement in theory and in action. Criminology \& Criminal Justice, 6(1), 83-106.

\section{https://doi.org/10.1177/1748895806060668}

Burnett, R., \& Maruna, S. (2004). So “Prison Works”, Does It? The Criminal Careers of 130 Men Released from Prison under Home Secretary Michael Howard. Howard Journal of Criminal Justice 43(4), 390-404. https://doi.org/10.1111/j.1468-2311.2004.00337.x

Burnett, R., \& McNeill, F. (2005). The place of the officer-offender relationship in assisting offenders to desist from crime, Probation Journal, 52(3), 247-68. https://doi.org/10.1177/0264550505055112

Bushway, S. D., Piquero, A. R., Broidy, L. M., Cauffman, E., \& Mazerolle, P. (2001). An empirical framework for studying desistance as a process. Criminology, 39(2), 491-515. https://doi.org/10.1111/j.1745-9125.2001.tb00931.x

Byrne, C. F., \& Trew, K. F. (2008). Pathways through crime: The development of crime and desistance in the accounts of men and women offenders. The Howard Journal of Criminal Justice, 47(3), 238-258. https://doi.org/10.1111/j.1468-2311.2008.00520.x

Carlton, B., \& Segrave, M. (2011). Women's survival post-imprisonment: Connecting imprisonment with pains past and present. Punishment \& Society, 13(5), 551-570. https://doi.org/10.1177/1462474511422174

Carlton, B., \& M. Segrave (Eds.) (2013). Women Exiting Prison: Critical Essays on Gender, PostRelease Support and Survival. Oxon: Routledge.

Carlton, B., \& Segrave, M. (2016). Rethinking women’s post-release reintegration and ‘success'. Australian \& New Zealand Journal of Criminology, 49(2), 281-299. https://doi.org/10.1177/0004865815573876

Carrington, K. (1998). Postmodern and feminist criminologies: Disconnecting discourses? International Journal of the Sociology of Law, 22(3).

Carlen, P. (1983). Women's imprisonment: A study in social control. London: Routledge and Kegan Paul.

Carlen, P. (1998). Sledgehammer: Women's Imprisonment at the Millennium. London: Macmillan. Chesney-Lind, M., \& Pasko, L. (2013). Girls, women and crime: Selected readings (2nd ed.). Los Angeles: Sage Publications.

Chesney-Lind, M., \& Shelden, R. G. (2004). Girls, delinquency, and juvenile justice (3rd ed.). Belmont: Thompson Wadsworth. 
Chesney-Lind, M. (1986). Women and crime: The female offender. Journal of Women in Culture and Society, 12(1), 78-96. https://doi.org/10.1086/494298

Chesney-Lind, M. (1989). Girls’ crime and woman’s place: Towards a feminist model of female delinquency. Crime and Delinquency, 35(1), 5-29. https://doi.org/10.1177/0011128789035001002

Clarke, R.V., \& Cornish, D.B. (1985). Modeling offender's decisions: A framework for research and policy. Crime and justice, 6, 147-185. https://doi.org/10.1086/449106

Cobbina, J., \& Miller, Jody. (2009). From prison to home: Women's pathways in and out of crime. ProQuest Dissertations Publishing. http://search.proquest.com/docview/305088589/

Covington, S. (1998). The relational theory of women's psychological development: Implications for the criminal justice system. In R. Zaplin (Ed.), Female crime and delinquency: Critical perspectives and effective interventions (pp.135-164). Gaithersburg: Aspen Publishers.

Cusson, M., \& Pinsonneault, P. (1986). The decision to give up crime. In D.B. Cornish \& R.V. Clarke (Eds.), The reasoning criminal (pp.72-82). New York: Springer-Verlag

Daly, K. (1992). A women’s pathway to felony court: Feminist theories of lawbreaking and problems of representation. Southern California Review of Law and Women's Studies, 2(1), 57-76.

DeHart, D. D. (2008). Pathways to prison: Impact of victimization in the lives of incarcerated women. Violence Against Women, 14(12), 1362-1381. https://doi.org/10.1177/1077801208327018

DeHart, D., \& Moran, R. (2015). Poly-victimization among girls in the justice system: Trajectories of risk and associations to juvenile offending. Violence Against Women, 21(3), 291-312. https://doi.org/10.1177/ 1077801214568355

Easteal, P. W. (1992). Women and crime: Imprisonment issues. Trends and issues in criminal justice. Canberra: Australia Institute of Criminology. https://aic.gov.au/publications/tandi/tandi35

Easteal, P. (2001). Women in Australian prisons: The cycle of abuse and dysfunctional environments. The Prison Journal, 81(1), 87-112. https://doi.org/10.1177/0032885501081001007

Farrall, S., \& Bowling, B. (1999). Structuration, human development and desistance from crime. British Journal of Criminology, 39(2), 252-67. https://doi.org/10.1093/bjc/39.2.253

Farrall, S., Bottoms, A., \& Shapland, J. (2010). Social structures and desistance from crime. European Journal of Criminology, 7(6), 546-570. https://doi.org/10.1177/1477370810376574

Farrall, S., \& Calverley, A. (2006). Understanding desistance from crime: theoretical directions in rehabilitation and resettlement. England: Open University Press. 
Farrington, D. (1992). Explaining the Beginning, Progress, and Ending of Antisocial Behaviour from Birth to Adulthood. In J. McCord (ed.), Facts, Frameworks, and Forecasts: Advances in Criminological Theory (pp.253-286). New Brunswick: Transaction Publishers.

Friestad, C., \& Skog Hansen, I. L. S. (2010). Gender differences in inmates anticipated desistance. European Journal of Criminology, 7(4), 285-298. https://doi.org/10.1177/1477370810363375

Gadd, D., \& Farrall, S. (2004). Criminal careers, desistance and subjectivity: Interpreting men’s narratives of change. Theoretical Criminology, 8(2), 123-56 https://doi.org/10.1177/1362480604042241

Galnander, R. (2019). Being Willing but Not Able: Echoes of Intimate Partner Violence as a Hindrance in Women's Desistance from Crime. Journal of Developmental Life Course Criminology 5(3), 437-460. https://doi.org/10.1007/s40865-019-00108-5

Garland, D. (2001). Mass imprisonment: Social causes and consequences. Thousand Oaks: Sage.

Gelsthorpe, L., Sharpe, G., \& Roberts, J. (2007). Provision for women offenders in the community. London: Fawcett Society.

Giordano, P., Cernkovich, S., \& Rudolph, J. (2002). Gender, crime and desistance: Toward a theory of cognitive transformation. American Journal of Sociology 107(4), 990-1064. https://doi.org/10.1086/ 343191

Glueck, S., \& Glueck, E. (1937). Later criminal careers. New York: Kraus.

Goffman, E. (1959). The presentation of self in everyday life. London: Penguin Books.

González-Monteagudo, J. (2011). Jerome Bruner and the challenges of the narrative turn: Then and now. Journal of Narrative Inquiry, 21(2), 295-302. https://doi.org/ 10.1075/ni.21.2.07go

Goulding, D. (2004). Severed connections: An exploration of the impact of imprisonment on women's familial and social connectedness. Perth: Murdoch University.

Halsey, M. J. (2008). Pathways into prison: Biographies, crimes, punishment. Current Issues in Criminal Justice, 20(1), 95-110. https://doi.org/10.1080/10345329.2008.12056189

Hampton, B. (1993). Prisons and women. Kensington: New South Wales University Press.

Hannah-Moffat, K. (2005). Criminogenic needs and the transformative risk subject. Punishment and Society 7(1), 29-51. https://doi.org/10.1177/1462474505048132

Hart, E. L. (2017). Women Prisoners and the Drive for Desistance: Capital and responsibilization as a barrier to change. Women \& Criminal Justice, 27(3), 151-169.

https://doi.org/10.1080/08974454.2016.1217814 
Healy, D. 2013. Changing Fate? Agency and the Desistance Process. Theoretical Criminology 17(4), 557-574. https://doi.org/10.1177/1362480613494991

Hollander, J.A., \& Gordon, H.R. (2006). The Processes of Social Construction in Talk. Symbolic Interaction, 29(2), 183-212. https://doi.org/10.1525/si.2006.29.2.183

Holtfreter, K., \& Morash, M. (2003). The Needs of Women Offenders. Women \& Criminal Justice, 14(2), 137-160. https://doi.org/10.1300/J012v14n02_07

King, R. D., Massoglia, M., \& MacMillan, R. (2007). The context of marriage and crime: Gender, the propensity to marry, and offending in early adulthood. Criminology, 45(1), 33-

65. https://doi.org/10.1111/j.1745-9125.2007.00071.x

Laub, J. H., \& Sampson, R. J. (2001). Understanding desistance from crime. Chicago: University of Chicago Press.

Laub, J. H., \& Sampson, R. J. (2003). Shared beginnings, divergent lives: Delinquent boys to age 70. Cambridge: Harvard University Press.

Lawrie, R. (2003). Speak out, speak strong: Rising imprisonment rates of Aboriginal women. Sydney: Aboriginal Justice Advisory Council. https://yamurrah.com.au/publications/

Leverentz, A. (2006). The Love of a Good Man? Romantic Relationships as a Source of Support or Hindrance for Female Ex-Offenders. Journal of Research in Crime and Delinquency, 43(4),459488. https://doi.org/10.1177/0022427806293323

Maidment, M. (2006). Doing time on the outside: Deconstructing the benevolent community. Canada: University of Toronto Press Incorporated.

Maruna, S. (1997). Going straight: Desistance from crime and self-narratives of reform. Narrative Study of Lives, 5, 59-93.

Maruna, S. (2001). Making good: How ex-convicts reform and rebuild their lives. Washington DC: American Psychological Association Books.

Maruna, S., \& Farrall, S. (2004). Desistance from Crime: A Theoretical Reformulation. Kolner Zeitschrift f ur Soziologie und Sozialpsychologie, 43, 171-94.

Massoglia, M., \& Uggen, C. (2007). Subjective desistance and the transition to adulthood. Journal of Contemporary Criminal Justice, 23(1), 90-103. https://doi.org/10.1177/1043986206298950

McAdams, D. (1996). Personality, modernity, and the storied self: A contemporary framework for studying persons. Psychological Inquiry, 7(4), 295-321. https://doi.org/10.1207/s15327965pli0704_1 
McIvor, G., Murray, C., \& Jamieson, J. (2004). Desistance from crime: Is it different for women and girls? In S. Maruna \& R. Immarigeon (Eds.), After crime and punishment: Pathways to offender reintegration (pp181-200). Cullompton: Willan Publishing.

McIvor, G. (2007). The nature of female offending. In R. Sheehan, G. McIvor \& C. Trotter (Eds.), What works with women offenders (pp.1-22). Cullompton: Willan Publishing.

McNeill, F., Anderson, K., Colvin, S., Overy, K., Sparks, R., \& Tett, L. (2011). Inspiring desistance? Arts projects and 'what works'. Justitiele Verkenningen, 37(5), 80-101.

Mishler, E. (1986). The analysis of interview narratives. In T. Sarbin (Ed.). Narrative psychology: The storied nature of human conduct (pp. 233-255). New York: Praege.

Morash, M., Haarr, R. N., \& Rucker, L. (1994). A comparison of programming for women and men in US prisons in the 1980s. Crime \& Delinquency, 40(2), 197-221. https://doi.org/10.1177/ $\underline{0011128794040002004}$

Mulvey, E. P., Steinberg, L., Fagan, J., Cauffman, E., Piquero, A. R., Chassin, L., Losoya, S. H. (2004). Theory and Research on Desistance from Antisocial Activity among Serious Adolescent Offenders. Youth Violence and Juvenile Justice, 2(3), 213-236. https://doi.org/10.1177/1541204004265864

Nugent, B., \& Schinkel, M. (2016). The pains of desistance. Criminology \& Criminal Justice, 16(5), 568-584. https://doi.org/10.1177/1748895816634812

O’Brien, P. (2001). Making it in the 'free world': Women in transition from prison. New York: State University of New York Press.

Österman, L. (2018). Penal Cultures and Female Desistance. London: Routledge.

Peacock, M. (2008). A third space between the prison and the community: Post release programs and re-integration. Current Issues in Criminal Justice, 20(2), 307-312.

Paternoster, R., \& Bushway, S. (2009). Criminology: desistance and the 'feared self': toward an identity theory of criminal desistance. Journal of Criminal Law and Criminology, 99, 1103-1227.

Piquero, A (2004). Somewhere between persistence and desistance: The intermittency of criminal careers. In R. Immarigeon \& S. Maruna (Eds). Offender re-entry and desistance (pp.102126). London: Willan.

Pollack, S. (2008). Locked in, locked out: Imprisoning women in the shrinking and punitive welfare state. https://www.wlu.ca/docsnpubs_detail.php?grp_id=1067\&doc_id=30852 
Pollack, S. (2009). You can't have it both ways: Punishment and treatment of imprisoned women. Journal of Progressive Human Services, 20(2), 112-128.

https://doi.org/10.1080/10428230903306344

Pollock-Byrne, J.M. (1990). Women, prison, and crime. Pacific Grove: Brookes/Cole.

Rafter, N. H. (1990). Partial justice (2nd ed.). New Jersey: Transaction Publishers.

Reisig, M. D., Holtfreter, K., \& Morash, M. (2006). Assessing recidivism risk across female pathways to crime. Justice Quarterly, 23(3), 384-405.

https://doi.org/10.1080/07418820600869152

Richie, B. (2001). Challenges incarcerated women face as they return to their communities:

Findings from life history interviews. Crime \& Delinquency, 47(3), 368-389.

https://doi.org/10.1177/0011128701047003005

Rodermond, E., Kruttschnitt, C., Slotboom, A.M., \& Bijleveld, C. C. (2016). Female desistance: A review of the literature. European Journal of Criminology, 13(1), 3-28. https://doi.org/10.1177/ $\underline{1477370815597251}$

Salisbury, E. J., \& Van Voorhis, P. (2009). Gendered Pathways: A Quantitative investigation of women probationers' paths to incarceration. Criminal Justice and Behavior, 36(6), 541-566. https://doi.org/10.1177/0093854809334076

Sampson, R.J., \& Laub, J.H. (1993) Crime in the making: pathways and turning points through life. London: Harvard University Press.

Sampson, R.J., Laub, J.H., \& Wimer, C. (2006). Does marriage reduce crime? A counterfactual approach to within-individual causal effects. Criminology 44(3), 465-508. https://doi.org/10.1111/j.1745-9125.2006.00055.x

Scraton, P., \& Moore, L. (2005). Degradation, harm and survival in a women's prison. Social Policy and Society, 5(1), 67-78. https://doi.org/10.1017/S1474746405002757

Segrave, M., \& Carlton, B. (2010). Women, trauma, criminalization and imprisonment. Current Issues in Criminal Justice, 22(3), 287-305. https://doi.org/10.1080/10345329.2010.12035887

Silverman, D. (2004). Qualitative research: Theory, method and practice. Thousand Oaks, CA: Sage.

Thompson, M., \& Petrovic, M. (2009). Gendered Transitions: Within-Person Changes in Employment, Family, and Illicit Drug Use. Journal of Research in Crime and Delinquency, 46(3), 377-408. https://doi.org/10.1177/0022427809335172 
Trotter, C., Sheehan, R., \& McIvor, G. (2006). Women after Prison. Australia: Monash University School of Social Work.

Uggen, C., \& Kruttschnitt, C. (1998). Crime in the breaking: Gender differences in desistance. Law and Society Review, 32(2), 33-366. https://doi.org/10.2307/827766

Uggen, C. \& Staff, J. (2001) Work as a turning point for criminal offenders. Corrections Management Quarterly, 5(4), 1-16.

Vaughan, B. (2007). The internal narrative of desistance. British Journal of Criminology, 47(3), 390-404. https://doi.org/10.1093/bjc/azl083

Wacquant, L. (2010). Crafting the neoliberal state: Workfare, prisonfare, and social insecurity. Sociological Forum, 25(2), 197-220. https://doi.org/10.1111/j.1573-7861.2010.01173.x

Walmsley, R. (2017). World Prison Population List (4th ed). London: Institute for Criminal Policy Research.

Ward, T., \& Maruna, S. (2007). Rehabilitation: Beyond the risk assessment paradigm. London, UK: Routledge.

Warr, M. (1998). Life-course transitions and desistance from crime. Criminology, 36(2), 183-216. https://doi.org/10.1111/j.1745-9125.1998.tb01246.x 